\title{
Transcatheter aortic valve implantation not preceded by balloon valvuloplasty in a patient with increased risk of stroke - a case report
}

Przezskórna implantacja zastawki aortalnej niepoprzedzona walwuloplastyką balonową u pacjenta ze zwiększonym ryzykiem wystąpienia udaru mózgu - opis przypadku

\author{
Wojciech Zimoch', Dorota Kustrzycka-Kratochwil', Artur Telichowski', Zdzisław Falkiewicz ${ }^{3}$, Piotr Kubler, \\ Krzysztof Reczuch ${ }^{1,2}$ \\ 1Department of Heart Diseases, Medical University of Wroclaw, Poland \\ ${ }^{2}$ Centre of Heart Diseases, Department of Cardiology, $4^{\text {th }}$ Clinical Military Hospital, Wroclaw, Poland \\ ${ }^{3} 2^{\text {nd }}$ Department of Anaesthesiology and Intensive Care, $4^{\text {th }}$ Clinical Military Hospital, Wroclaw, Poland
}

Post Kardiol Interw 2012; 8, 1 (27): 70-74 DOI: $10.5114 /$ pwki.2012.28073

\begin{abstract}
Until recently, balloon valvuloplasty (BAV) was considered as a necessary step during transcatheter aortic valve implantation (TAVI). It was proven that BAV increases the risk of stroke and conduction disturbances requiring permanent pacemaker implantation. Omitting aortic valvuloplasty can increase the safety of percutaneous treatment of severe aortic stenosis.
\end{abstract}

Key words: transcatheter aortic valve implantation (TAVI), baloon valvuloplasty, stroke

\section{Streszczenie}

Walwuloplastyka balonowa (balloon valvuloplasty - BAV) do niedawna była uznawana za niezbędny element zabiegów przezskórnej implantacji zastawki aortalnej (transcatheter aortic valve implantation - TAVI). Wykazano, że BAV zwiększa ryzyko wystąpienia udaru mózgu i zaburzeń przewodzenia wymagających implantacji układu stymulującego serce. Modyfikacja zabiegów TAVI pozwalająca uniknąć walwuloplastyki balonowej daje nadzieję na zwiększenie bezpieczeństwa przezskórnego leczenia stenozy aortalnej.

Słowa kluczowe: przezskórna implantacja zastawki aortalnej (TAVI), walwuloplastyka balonowa, udar mózgu

\section{Introduction}

Randomized clinical trials have demonstrated the efficacy of TAVI procedures, but concern was raised about the reports regarding the frequency of stroke as a complication of these procedures [1, 2]. Until recently, balloon valvuloplasty (BAV) was considered as a necessary step during transcatheter aortic valve implantation to facilitate introduction, positioning and expansion of the prosthesis, but there is no proof demonstrating the efficacy of this procedure [3]. In addition, a relation was found between BAV and many complications of TAVI such as distal embolization, stroke and conduction disturbances [4].
We present a case of the TAVI procedure not preceded by balloon valvuloplasty in a patient with high risk of periprocedural stroke related to the presence of an additional echo on the aortic valve observed with echocardiography.

\section{Case report}

An 83-year-old man, a non-smoker, with a known acquired heart disease in the form of severe aortic valve stenosis (AS), was admitted to the Department of Cardiology of the $4^{\text {th }}$ Clinical Military Hospital in Wroclaw for the qualification for surgery. He had a history of two episodes of presyncope which occurred during exercise: 
one 5 months before the admission and another one on the day of admission.

On admission he was in a stable condition, with ECG showing sinus tachycardia (100 bpm) and ST-segment depression in leads II, III, aVF, V4-V6 (which remained stable in following registrations), RR 135/80 mm Hg. Physical examination revealed auscultatory changes typical for aortic stenosis. There were no abnormalities in laboratory findings and markers of myocardial necrosis were not elevated.

Transthoracic echocardiography (TTE) demonstrated normal size of the heart chambers, preserved left ventricular systolic function ( $E F=65 \%$ ) with concentric left ventricular hypertrophy and signs of complex aortic valve disease with predominating severe stenosis - maximal transaortic pressure gradient $115 \mathrm{~mm} \mathrm{Hg}$, mean $97 \mathrm{~mm} \mathrm{Hg}$, aortic valve area calculated with the continuity equation (AVA) $0.5 \mathrm{~cm}^{2}$. Transoesophageal echocardiography (TEE) showed a calcified tricuspid aortic valve, annulus diameter $27 \mathrm{~mm}$, left ventricular outflow tract (LVOT) $24 \mathrm{~mm}$. There was also an additional mobile echo $(3 \mathrm{~mm} \times 6 \mathrm{~mm})$ characteristic for thrombus or vegetation and invisible in TTE. It was located on the aortic side of the posterior aortic cusp (Figure 1). The diagnosis of active infective endocarditis (IE) was excluded because of the lack of clinical or laboratory signs of inflammation. Coronary angiography did not demonstrate significant lesions in the coronary arteries.

Although the risk of peri-procedural death calculated for the surgical procedure was considered as intermediate (6 points $-11.2 \%$ ) according to the EuroSCORE scale, the patient refused surgery and was qualified for the TAVI procedure.

The TAVI procedure was performed under general anaesthesia, with access via the right femoral artery using the $18 \mathrm{~F}$ CoreValve system. Despite a very tight aortic valve stenosis (AVA $0.5 \mathrm{~cm}^{2}$ ) the decision not to perform BAV was made because of concerns about the increased risk of mobiliza-

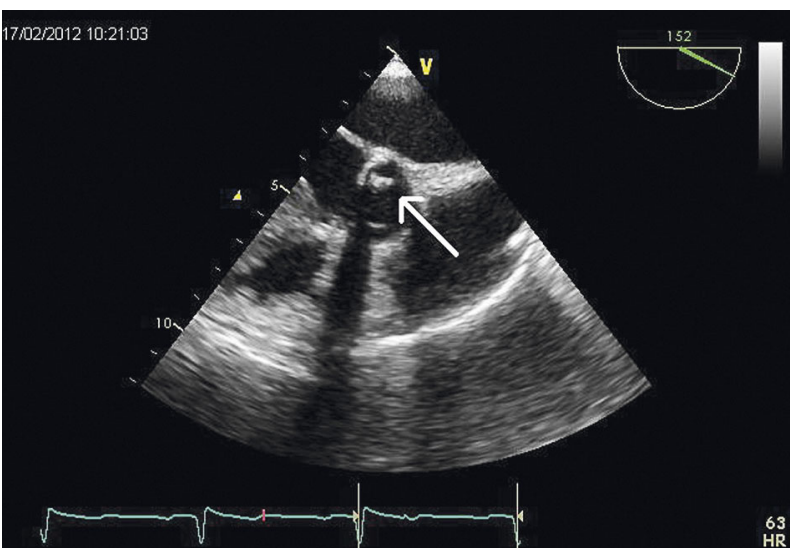

Fig. 1. TEE. Additional echo on posterior cusp of aortic valve

Ryc. 1. TEE. Echo dodatkowe na płatku niewieńcowym zastawki aortalnej tion of the balloting structure still visible on TEE. The fact that introduction and complete expansion of the prosthesis may be difficult and post-dilation may be necessary was taken into account. Introduction of a $29 \mathrm{~mm}$ diameter prosthesis into the position of the aortic valve was performed without any complications, but hypotonia 55/30 mm Hg (baseline 100/60 mm Hg) occurred immediately after expansion of the prosthesis. It was caused by severe aortic valve regurgitation (left ventricular end-diastolic pressure [LVEDP] $25 \mathrm{~mm} \mathrm{Hg}$ ) (Figure 2). Fluoroscopy demonstrated incomplete expansion of the prosthesis (Figure 3). Therefore imme-

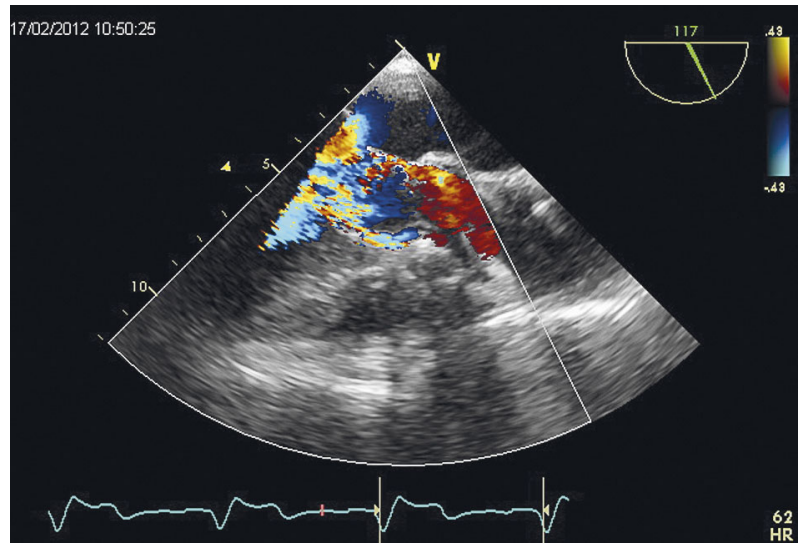

Fig. 2. TEE, long axis. Paravalvular leak immediately after implantation of CoreValve bioprosthesis Ryc. 2. TEE, oś długa. Niedomykalność aortalna o charakterze przecieku okołozastawkowego, bezpośrednio po implantacji bioprotezy CoreValve

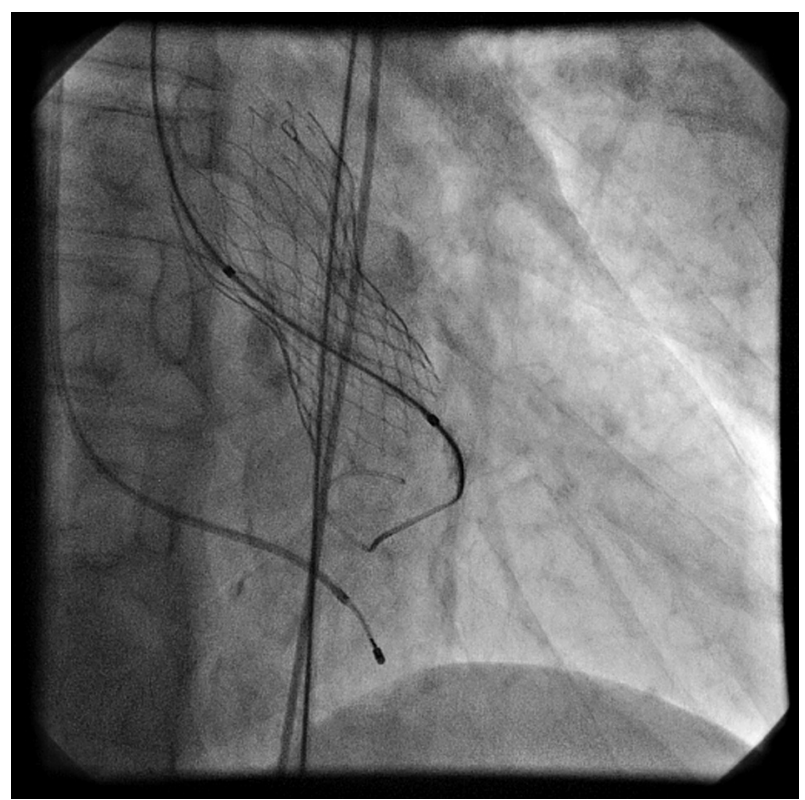

Fig. 3. CoreValve bioprosthesis immediately after implantation, not fully expanded. RAO

Ryc. 3. Zastawka CoreValve bezpośrednio po implantacji, nie w petni rozprężona. $R A O$ 


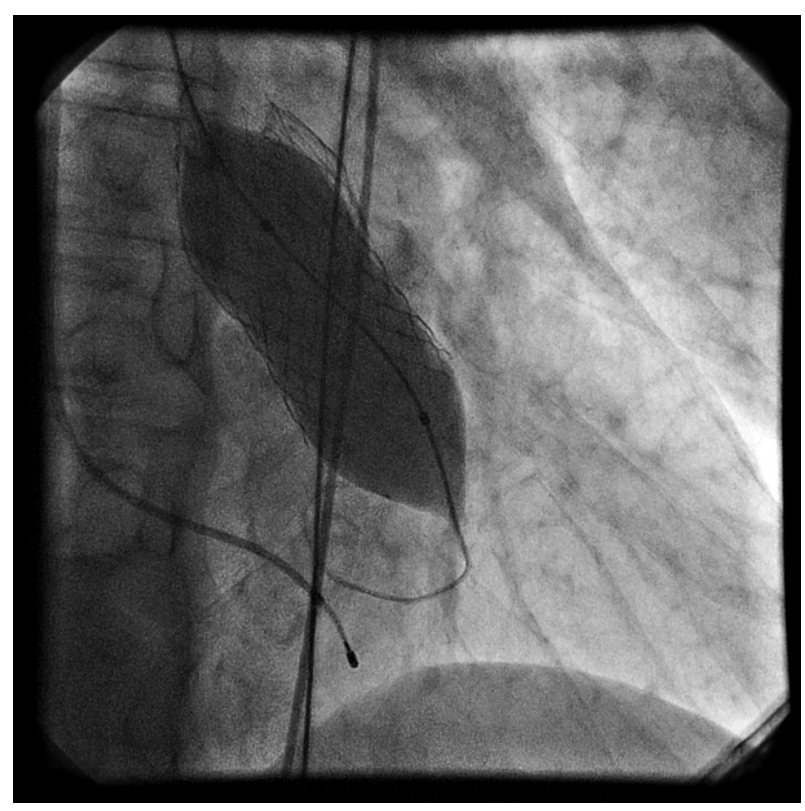

Fig. 4. Postdilatation, full expansion of transcatheter heart valve. RAO

Ryc. 4. Postdylatacja, catkowite rozprężenie zastawki. $R A O$

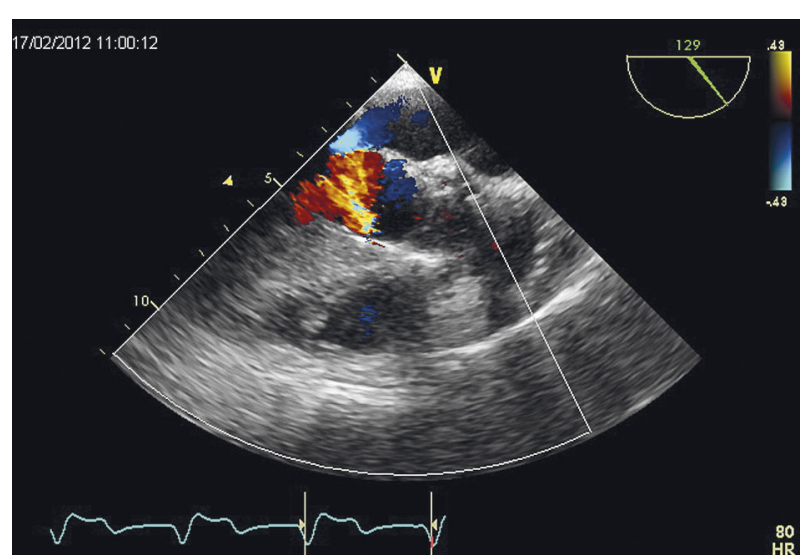

Fig. 5. TEE, long axis. Aortic regurgitation after postdilatation

Ryc. 5. TEE, oś długa. Niedomykalność aortalna po postdylatacji

diate post-dilation of the valve using a $28 \mathrm{~mm}$ balloon was performed, which resulted in decrease of the perivalvular leak (to ++), increase of aortic pressure to $105 / 60 \mathrm{~mm} \mathrm{Hg}$, decrease of LVEDP to $12 \mathrm{~mm} \mathrm{Hg}$ and full expansion of the prosthesis (Figures 4, 5). Expansion of the balloon led to widening of the QRS complexes characteristic for left bundle branch block (LBBB) and prolongation of the PQ interval visible on ECG monitoring. Due to a change of anatomical conditions caused by implantation of the prosthesis the additional echo attached to the posterior aortic cusp became invisible in TEE.

The further clinical course was typical and there were no complications. Transthoracic echocardiography per- formed immediately after the procedure demonstrated maximal and mean pressure gradient across the valve of respectively $12 \mathrm{~mm} \mathrm{Hg}$ and $8 \mathrm{mmHg}$ and a moderate reverse flow to the left ventricle (up to ++ ). There were no neurological complications throughout the hospital stay. On the fourth day after TAVI the patient underwent implantation of a DDDR pacemaker because of the asymptomatic conduction disturbances (PQ 280 ms, QRS 160 ms, LBBB). Control echocardiographic examinations demonstrated significant regression of the aortic regurgitation (up to maximally + ). The patient was discharged from hospital on the $7^{\text {th }}$ day after the procedure with the recommendation of adoption of the following drugs: clopidogrel $(1 \times 75 \mathrm{mg}$ daily for 3 months), aspirin $(1 \times 75 \mathrm{mg})$, atorvastatin $(1 \times 20 \mathrm{mg})$, carvedilol (12.5 mg and $6.25 \mathrm{mg}$ ) as well as pantoprazole $(1 \times 20 \mathrm{mg})$.

\section{Discussion}

Stroke is a serious complication of TAVI. It occurs more often after transcatheter than classic surgical procedures [2]. During 30-day and 1 year observation in the PARTNER $A$ and $B$ studies, stroke was detected respectively in $4.7 \%$ and $6.7 \%$ and in $6 \%$ and $10 \%$ of patients [1, 2]. A meta-analysis by Eggebrecht et al. based on $10000 \mathrm{TAVI}$ procedures demonstrated that stroke/TIA (transient ischaemic attack) occurred in 3.3\% of patients during 30-day follow-up [5].

Observations made using diffusion-weighted magnetic resonance imaging (DW-MRI) demonstrated clinically silent ischaemic foci localized in the central nervous system (CNS) in $73-91 \%$ of patients undergoing TAVI $[6,7]$. Their clinical significance in patients treated percutaneously remains unexplained, but there is a documented relation between these kinds of foci and impairment of cognitive function in patients after surgical procedures [8]. Despite various causes of TAVI-related stroke, episodes of distal embolization with material detached from the valve or aortic arch during BAV, catheter introduction through the valve or valve implantation are considered as the main aetiological factors [9].

The efficacy of mechanical CNS protection systems has been demonstrated during procedures on carotid arteries, and similar technology is currently being introduced for TAVI procedures.

Three CNS protection systems dedicated to TAVI are being tested: Embrella (Edwards Lifesciences, Irvine, CA, USA), SMT-Shimon Embolic protection Filter - SHEF (SMT Medical, Herzliya Pituach, Israel) and Claret (Claret Medical, Inc. Santa Rosa, CA, USA) [9].

The first two devices are known as "embolic deflection systems" and act as a shield which redirects embolic material away from arteries supplying the brain in the direction of the peripheral circulation. The Claret device consists of 2 filters and allows the embolic material to be captured and evacuated out of the circulatory system. Currently there are no randomized studies showing the efficacy of these devices, but initial reports are promis- 
ing [10]. Unfortunately, none of these systems is available in Poland.

Until recently BAV was considered as a mandatory element of TAVI and it is still recommended before valve implantation in current ESC guidelines [3]. There are no studies showing what percentage of strokes during TAVI is related directly to BAV, but it was demonstrated that isolated BAV does not influence the natural history of AS or reduce mortality and is related to release of embolic material $[1,4]$. The BAV requires the use of rapid ventricular pacing (RVP) up to $180 \mathrm{bpm}$, which leads to functional cardiac arrest lasting up to $30 \mathrm{~s}$. Furthermore, conduction disturbances related to TAVI appear directly after BAV in $46 \%$ of patients [11]. Strong extension of the aortic annulus during BAV may also cause acute and haemodynamically significant aortic regurgitation [4, 12]. Rapid ventricular pacing leads to transient ischaemia of the heart, brain and kidneys. In patients with impaired left ventricular function, this may cause an acute hemodynamic failure and promote the occurrence of the systemic inflammatory response syndrome (SIRS), a complication related to high peri-procedural mortality [13].

The presence of the additional, balloting echo on the aortic valve in the present case raised concerns about the risk of distal embolization and neurological complications and influenced the choice of a different strategy than the one routinely used. The change of anatomical conditions of the native aortic valve after expansion of the CoreValve bioprosthesis did not allow assessment of whether the additional echo was released into the circulatory system or whether it was still attached to the cusp because it was located below the frame of the prosthesis. Therefore we do not know and we will not be able to find out whether prosthesis implantation without pre-dilation influenced the asymptomatic course.

In a pilot, non-randomized study, Grube et al. compared the results of $60 \mathrm{TAVI}$ procedures with the use of CoreValve $18 \mathrm{~F}$ not preceded by BAV with a retrospective group of patients treated traditionally [12]. The efficacy of the procedure was $96.7 \%$ and post-dilation was required in $16.7 \%$ of patients. Thirty-day observation of the studied group revealed a decrease of mortality (6.7\% vs. $14.3 \%)$, myocardial infarction (0 vs. 5.6\%), stroke/TIA (5\% vs. $11.9 \%$ ) and conduction disturbances requiring pacemaker implantation (11.7\% vs. $27.8 \%)$, but a more frequent occurrence of aortic regurgitation was observed (58\% vs. $41 \%$ ) [12]. The number of patients included in the study as well as the methodology suggests cautious interpretation of the results, but the study gives hope for further improvement of TAVI results, especially in patients with impaired left ventricular systolic function who have the highest risk of BAV and RVP complications.

It should be noted that avoidance of RVP is technically impossible in the case of prostheses expanded on balloons. Therefore, the results of the above study may be an important argument for using self-expanding TAVI systems (not preceded by BAV) in patients with advanced heart failure. The randomized SIMPLYFy TAVI trial (ClinicalTrials.gov NCT01539746) that starts in April 2012 will help in detailed assessment of the efficacy and safety of TAVI procedures not preceded by BAV.

Much attention is paid to conduction disturbances following TAVI, especially with the use of the CoreValve system. It was demonstrated that conduction disturbances during TAVI occur in $56 \%$ of cases before the prosthesis expansion and are most frequently related to BAV (47\%) [11]. The occurrence of conduction disturbances directly after post-dilation and not after prosthesis expansion observed in our case is in our opinion an interesting observation and is in line with the cited reports. It gives hope that omitting BAV may decrease the frequency of pacemaker implantation in patients undergoing CoreValve implantation.

The TAVI is a very new and promising procedure and therefore its modifications may allow us to increase the population of patients who benefit from transcatheter treatment.

\section{References}

1. Leon MB, Smith CR, Mack M, et al. Transcatheter aortic-valve implantation for aortic stenosis in patients who cannot undergo surgery. N Engl J Med 2010; 363: 1597-1607.

2. Smith CR, Leon MB, Mack MJ, et al. Transcatheter versus surgical aortic-valve replacement in high-risk patients. N Engl J Med 2011; 364: 2187-2198.

3. Vahanian A, Alfieri O, Al-Attar N, et al. Transcatheter valve implantation for patients with aortic stenosis: a position statement from the European association of cardio-thoracic surgery (EACTS) and the European Society of Cardiology (ESC), in collaboration with the European Association of Percutaneous Cardiovascular Interventions (EAPCI). Eurolntervention 2008; 4: 193-199.

4. Percutaneous balloon aortic valvuloplasty. Acute and 30-day follow-up results in 674 patients from the NHLBI Balloon Valvuloplasty Registry. Circulation 1991; 84: 2383-2397.

5. Eggebrecht $H$, Schmermund A, Voigtländer T, et al. Risk of stroke after transcatheter aortic valve implantation (TAVI): a meta-analysis of 10,037 published patients. Eurolntervention 2012 Mar 6. pii: 20120213-00. Epub ahead of print.

6. Kahlert P, Knipp SC, Schlamann M, et al. Silent and apparent cerebral ischemia after percutaneous transfemoral aortic valve implantation: a diffusion-weighted magnetic resonance imaging study. Circulation 2010; 121: 870-878.

7. Astarci P, Glineur D, Kefer J, et al. Magnetic resonance imaging evaluation of cerebral embolization during percutaneous aortic valve implantation: comparison of transfemoral and trans-apical approaches using Edwards Sapiens valve. Eur J Cardiothorac Surg 2011; 40: 475-479.

8. Barber PA, Hach S, Tippett LJ, et al. Cerebral ischemic lesions on diffusion-weighted imaging are associated with neurocognitive decline after cardiac surgery. Stroke 2008; 39: 1427-1433.

9. Van Mieghem NM, Serruys PW. Embolic protection devices during TAVI - the "proof of the pudding". Eurolntervention 2012 Mar 9. pii: 20120301-00.

10. Naber CK, Ghanem A, Abizaid AA, et al. First-in-man use of a novel embolic protection device for patients undergoing transcatheter 
aortic valve implantation. Eurolntervention 2012 Mar 9. pii: 20120213-01.

11. Nuis RJ, Van Mieghem NM, Schultz CJ, et al. Timing and potential mechanisms of new conduction abnormalities during the implantation of the Medtronic CoreValve System in patients with aortic stenosis. Eur Heart J 2011; 32: 2067-2074.

12. Grube E, Naber C, Abizaid A, et al. Feasibility of transcatheter aortic valve implantation without balloon pre-dilation: a pilot study. JACC Cardiovasc Interv 2011; 4: 751-757.

13. Sinning JM, Scheer AC, Adenauer V, et al. Systemic inflammatory response syndrome predicts increased mortality in patients after transcatheter aortic valve implantation. Eur Heart J 2012 Jan 26. Epub ahead of print. 